\section{The Role of Sohag National Museum in Reflecting Egyptian Tangible and Intangible Heritage}

Elham Salah Eldin Mohamed Alv, Alv Omar Abdallah and Guido Fackler

\section{Abstract}

Display can drive the museum's message. It is a powerful way to take a topic with cultural value and make it visible and tangible for museum visitors. There are a number of qualities that define an excellent museum display; the most important one is an engaging story. In the case of the regional museums of Upper Egypt, several approaches to displaying Egyptian heritage are presented. Such museums are shaped by evolving community values and senses of Egyptian history where every museum tells a different story. The objective of this paper is to clarify the current display of regional museums in Upper Egypt especially in the Museum analyzing its mission, its civic and social responsibilities. Effective storytelling, object material cultural and collection interpretation in Sohag National Museum's display recount historical events from a certain perspective and provide a stimulating experience that captures visitors' full attention.

\section{Key Words}

Display - storytelling- perspective- visitors'experience

\section{Introduction}

Storytelling has a critical role in human evolution. Using storytelling in the display of Egyptian Museums is a fundamental ask of Museums Sector at the Egyptian Minisistry of Antiquities. Storytelling adds a flavor to the fact and increases the interest in knowing. Using such interpretation tool at museums in Egypt is the latest trend. Display through storytelling enables the visitor to understand why the object is on display. Relevant stories of the museums' objects reveal both the tangible and intangible heritage of the nation where every object has a story to tell. ${ }^{2}$ The paper aims at identifying such interpretation tool that currently considered in the museums of Upper Egypt, where using storytelling in the display provides the communication between the exhibit and the visitor. ${ }^{3}$ The paper aims at illustrating storytelling as a method of interpretation in the most recently opened museums in Egypt, where planning the displays of such museums started with research of the objects themselves and the stories they can tell .The Sohag National Museum is the case study where the new approach of the display facilitates the communication between the material cultural heritage and the visitors.

\section{The Mission of the Museum Sector, Ministry of Antiquities.}

The Museums Sector in Egypt is undergoing a big transformation in the last decade; a lot of this transformation is due to the convenient strategy. The core aims are investigating the current status of the museums such as historic building, collection, and information, as well as architectural, artistic, cultural, and social information. The strategy seeks to build communities nationally and internationally through education, and public programs that promote collaboration and the exchange of ideas. It seeks to enrich lives by creating meaningful experiences for all generations who visit the museum. The mission is focusing on collecting preserving, researching, interpreting and exhibiting collections related to the history of Egypt, engaging audiences with the unique stories of Egyptian heritage, managing and conserving the collection and making it accessible to as many people as unique stories of Egyptian heritage, managing and conserving the collection and making it accessible to as many people as possible both for Egyptian and international visitors. As such, it plays a leading role in stimulating audiences to look beyond communities in unexpected and stimulating ways, engaging the public with the Egyptian heritage, and inspiring the public to go farther and deeper into culture and history, and Communicating with audiences in ways that go beyond simply presenting historical facts, offering inspiration through diverse curatorial approaches and exciting programs. ${ }^{4}$ The newly inaugurated regional museums in Egypt considered the core aims of the Museums Sector, and the current development approaches included changing the museum displays and installing new lighting and security systems. Since 2015, the Museum Sector set up a special plan to reactivate the absent role of the museums in Egypt, especially the regional museums through community engagemen and museums outreach programs.

\section{The Soft Power of the Regional museums in Egyp}

Museums and cities throughout the world are connecting in a soft power embrace. ${ }^{5}$ Museums today shape the soft power and use its spaces not just for knowledge or education but the power of correcting, solving and changing thoughts and behavior in the right directions. The term "Soft power" means the ability to shape the preferences of others. It is the ability to persuade others instead of using the power of the economy or military strength where the culture and museum as a soft power play a major role ${ }^{6}$. The Regional Museums in Egypt utilize the soft power which is the influence behavior using persuasion, attraction or agenda setting. The Regional Museums have several solt power resources which mean intangible resources such as ideas, knowledge, values and culture. Political scientist Joseph Nye, who first formulated the term "soft power" in 1990, recently explained how soft power has increased dramatically in the 21 st century as the Information Revolution helped to distribut information of all kinds worldwide? ${ }^{7}$.

Analyzing one of the recently inaugurated Regional Museums in Egypt (The Sohag National Museum)

The newly inaugurated regional Museums in Egypt is part of the cultural Sector strategy to improve and develop the Egyptian governorates. The Sohag National Museum was inaugurated by the Egyptian President Abdel Fatah al-Sisi on 13 Augus 2018. The museum is highlighting the Egyptian identity and the history of Sohag as one of the major cities in Upper Egypt. "Fig 1".The museum is a regional museum that is shaped by evolving community values and senses of the Egyptian history, influenced by philosophical ideas and reflecting various types of communications and messages. The procedures of setting the Sohag National Museum reflect its importance.

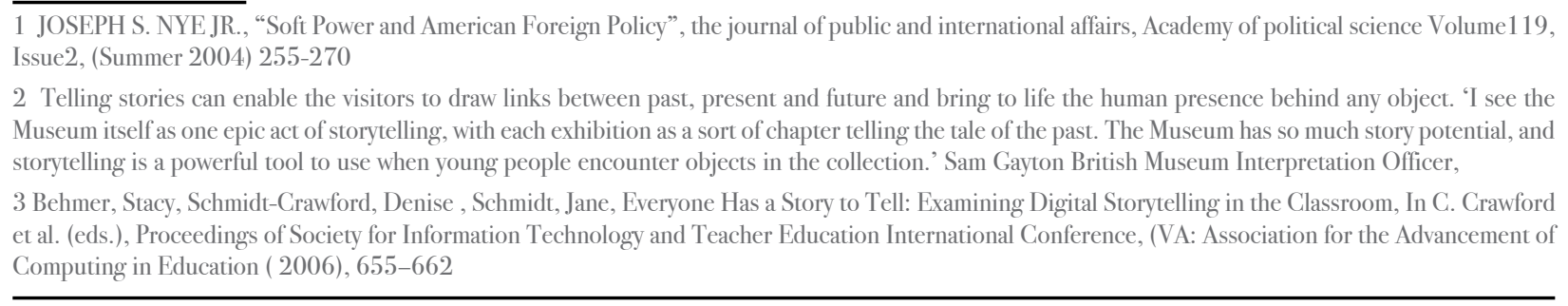

4 " "A mission statement drives everything the museum does; vision, policy-making, planning, and operations are all extensions of a museum's mission. The 5 Gall Dexter Lord, Ngarre Blankenberg, Introduction: Why Cities, Museums and Soft Power( Washington, DC: The AAM Press American Alliance

6 Joseph Nye, Soff Power ar
119, (Jume 2004) $255-270$

7 Gail Dexter Lord, Ngaire Blankenberg, Introduction: Why Cities, Museums and Soff Power. 


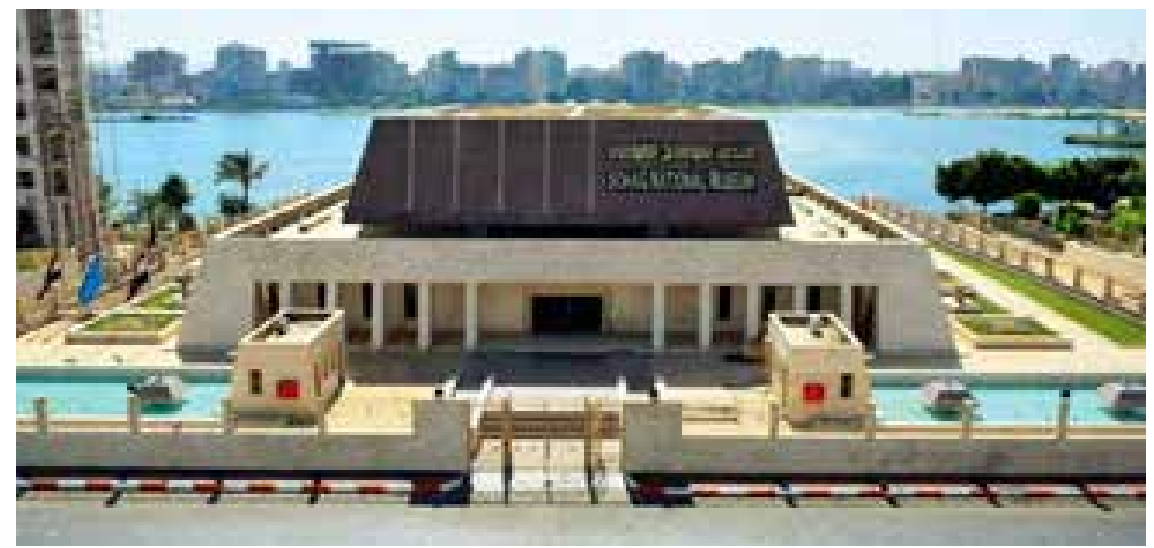

Fig.1. the photo shous Sohag national museum building and land escape. Photo br Researcher 2018

In 1989, the governor of Sohag made a regulation for building a regional museum in Sohag and devoted about 56.000 square meters close to the Nile River which is a real distinguished location. The work started in 1993, and then it had been stopped in 1996 due to the technical and interior design issues. The work resumed in 2006 and stopped again in 2010. In 2015, the head of the Egyptian Museums' Sector in cooperation with the head of the projects' sector at the Egyptian Ministry of Antiquities studied the financial situation of the museum. In 2016, the work was resumed. The Museums' Sector has taken the necessary steps in cooperation with the projects' sector with the aim of improving the accessibility of Sohag Museum. Museum accessibility is a vital element where it is merged by which product, device, service, environment, and knowledge are available for all people irrespective of age, social level, educational or culture level, sex, or disability". "Fig 2"

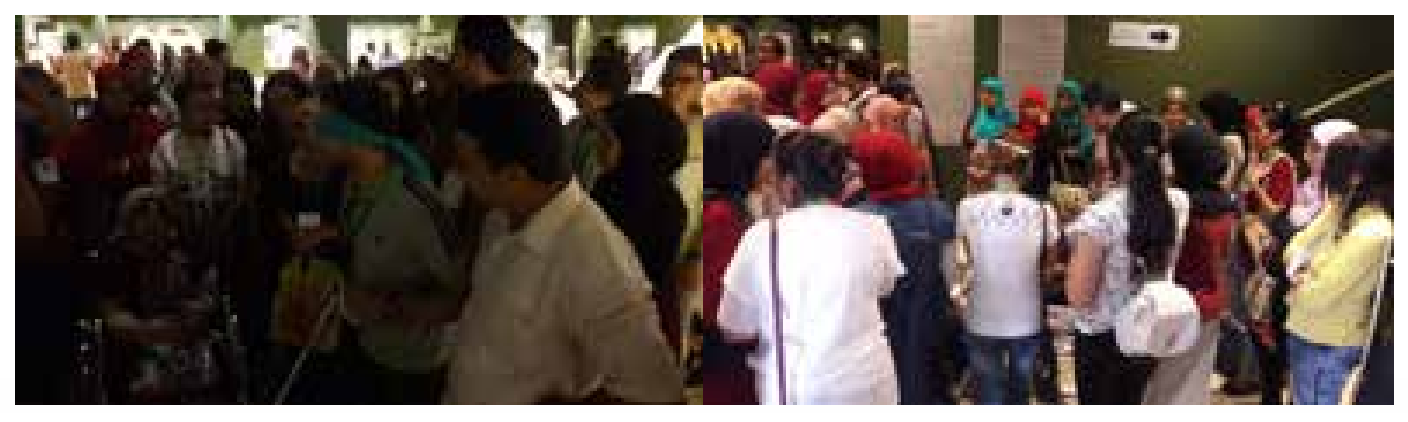

2 the hes

In terms of facilitating the aspects of the accessibility of Sohag Museum, the Museums' Sector presented the following facilities to the visitors: free guiding tours in the galleries to the Egyptian community, visitors' services, policemen and guards in charge of presenting information and answering any inquiries.

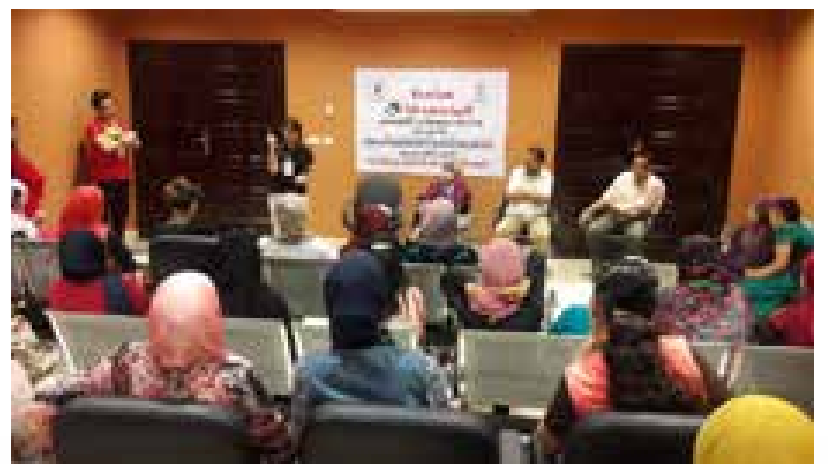

Fig.3.3. The photo shous curators and volumteers during one of the workshops. for
the disabled and accessibility. Photo by Sohag Musseum curators 2018 .

Many museums use appropriate museum display or exhibition techniques and elaborate accessibility resources such as listing devices, Braille signage and leaflets with large print letters for visually-impaired people. ${ }^{9}$ Nowadays museums' accessibility is an important ethic and modern museums scenario offer their visitors accessibility resources of all types of knowledge. ${ }^{\prime \prime}$ Museum professionals and other fields "professionals created plans for museums accessibility to fulfill visitors" needs. "Fig 3 " The enhancement accessto the context of culture and education is based on museums collections. The individual should acces the physical environment and the contents in museums regardless of their abilities and interests."

Museums tackle expressing itself inside and outside its physical places through spaces, museography, interpretation tools, real and virtual environment, and activities ${ }^{2}$. Museums today focus on information access to new public efficiency, moderate puline ${ }^{13}$. pubice information, access and mobility, comfort, safety, knowledge and experiences. Sohag Nuseum ollers a welcoming space that is

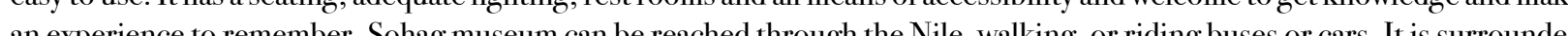
by by a lice wite la rese “T

heelchairs for Sohag Museum as well as providing traing en" made museum labels in Braille way for serving blind people and providur

. edge making families relax and attempt to solve their problems and take in 作 responsibilities of social development ${ }^{15}$. They always try to find ways and means to facilitate the communication between the

9 Louise Ravelli, Making Language Accessible: Successful Text Writing for Museum Visitors, Linguistics and Education 8 (England The University of Nev

10 Ted Anshacher, nakng evibits engoging and interesting. Curator Museum Journal, Volume45. Issue3 (July 2002), $167-173$

11 Barbara J. Soren, Museum experiences that change visitors, Museum Management and Curatorship Volume 24, - Issue 3., 2009 233-251

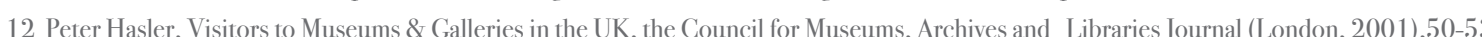

13 Beverly Serell Paving Auention: Visions ond

14 Michael O. Martin, Ina V.S. Mullis, Albert E. Beaton, Eugenio J. Gonzalez, Teresa A. Smith, and Dana L. Kelly, Science achievement in the primary school 1997),

15 Moutinho M., Evolving definition of sociomuseology proposal for reflection. Cadernos de Sociomuseologia, 38, 27-31. Organizzação para a Cooperaç্য e Desenvolvimento Económicos (OCDE) (2006). Competências en ciências para o mundo de amanhâ. Volume 1: Análise. IScience competencies for

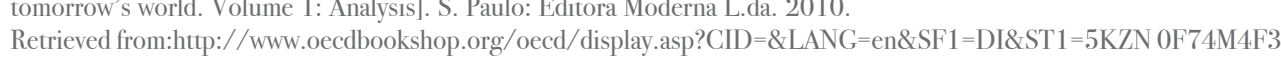


collections and the public. Generally, it is difficult to understand the way visitors interpret the museum and the story it tells hrough artifacts and information resourcs. ${ }^{16}$ Ineractive communication sa way to convert he meaning of the exhibit to micro text and micro context and to answer all social broadcast.

\section{The display}

Display is shedding the light on the storytelling approach. It was empowered by themes where each gallery has a special theme Each showcase has a key object that tells a specific story, while other representative objects take part in the story. The printed interpretation materials such as graphics and labels are used to provide a better understanding and to deliver the told message. The interpretation of Sohag museum collections and museum display can help the curators, volunteers and educators to organize the lifelong programs and social development workshops and convince more and more people to understand museums' role. Interpretation of the museum collections and museum display context will help Sohag museum staff to set up programs for formal, non formal and informal and lifelong learning which help people who might be intolerant to the structure and rigidity of regular educatio

The Sohag National Museum consists of two floors. The first floor consists of six exhibition galleries presenting certain kings and important personalities in the history of Egypt with a focus on Upper Egypt. There are three galleries on each side, while each gallery illustrates a different theme. The middle space between the six rooms' displays several roval statues representing the different historical periods in ancient Eoypt "Fig

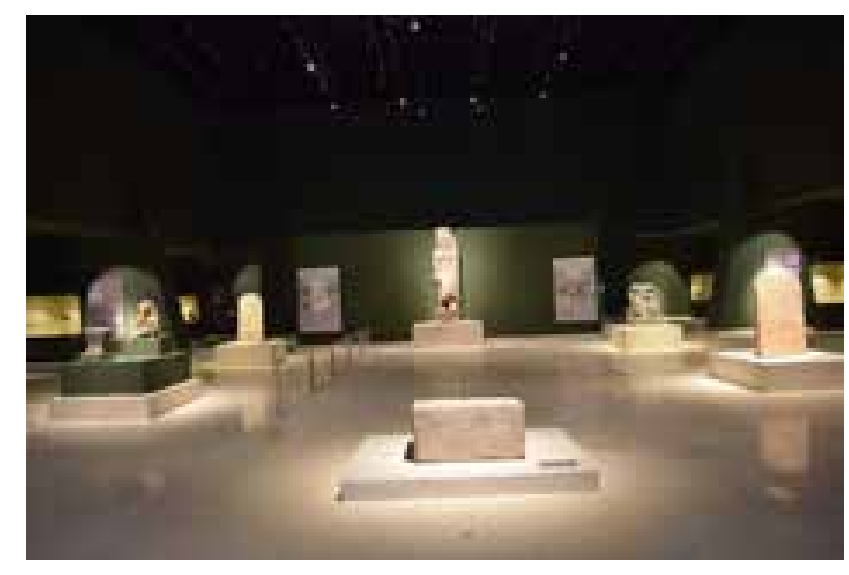

4 phot show

The collection reflects the life of an Egyptian family through history and the role of Egyptian women in their families, particularly in Upper Egypt. The upper floor exhibits also the folk heritage of the governorate, its most important ancient rulers, and its crafts and industries. Sohag played a prominent role in ancient Egyptian history. It was probably the home of the great kings who united the north and the south. Some of the kings of the First and Second Dynasties build their tombs in Abydos. ${ }^{18}$. The concept of using storytelling in display meets the mission of Sohag museum that designed to make all the objects of the collection available to the public for their edification and enjoyment.

Storytelling, in the context of archeological museums, is a method of communicating the qualities and attributes of history through a story where visitors can learn and understand the message the eye cannot see. Museum during the 1930s. This concept began with the idea of a working exhibit. A working exhibit allowed visitors to participate in a hands-on learning experience. "Fig.5"

$\overline{16}$ Ellien Hooper-Greenhill,. Education, communication and interpretation (Roultedge, 2006) p76-103

17 Hannah Paddon, Redisplaying Museum Collections: Contemporary Display and Interpretation in British Museums 1st Edition, (London, 2014), 100-184 18 Walter B Emery, A funerary repast in an Egyptian tomb of the archaic period, Leiden, Nederlands Instituut voor het Nabijic Oosten, 1962).

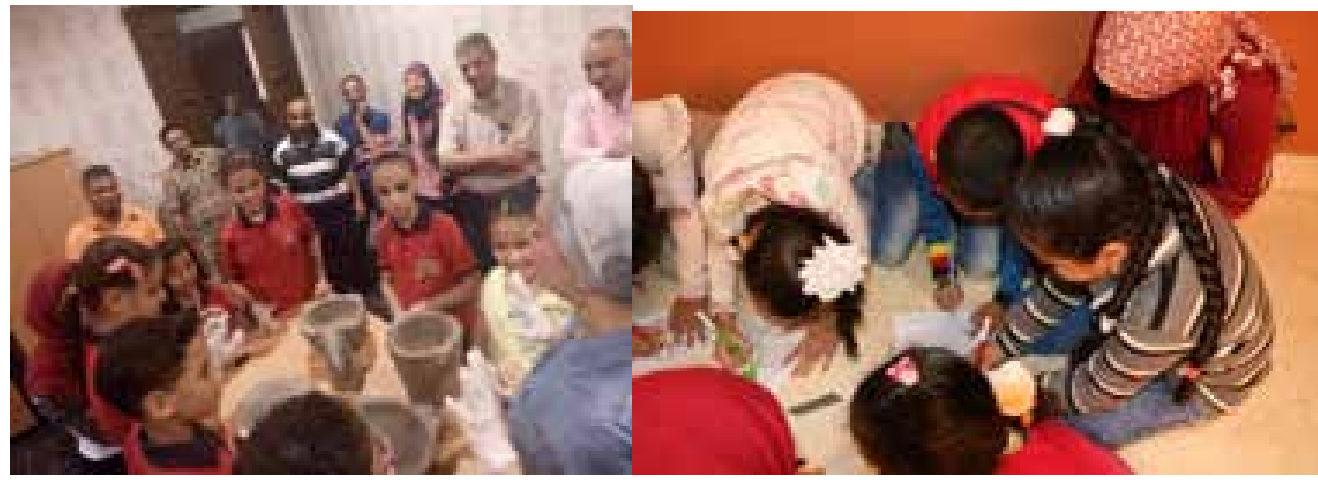

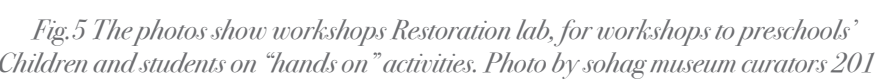

Nowadays, museums are not only serving schools or formal education; they became more open to general diverse visitors. Museums' objects as material culture are advantageous, facilitating the visitor's motivation for non-formal learning.' ${ }^{\prime}$ Regional Museums in Egypt have been able to utilize storytelling techniques not only to engage visitors with past history and memories, but also to illustrate their missions. Stories and storytelling are international aspects of human communication. Stories are like hidden artifacts and preserved memories of people and they save our culture s heritage. Storytelling support literacy developmentin national curricula. The smart storyteller is the one who can link the curricula to the museum' objects for a range of subjects such as history, religious studies, geography, English language and literature. ${ }^{20}$

\section{The Museums' Focal Objects that tell the Story of Display}

Focal objects tell the stories of lives that reflect not only the material culture but also the social beliefs, customs, and traditions In the case of Sohag National Museum display, the display was designed to identify such stories where the focal object in every hall tells a story. The focal objects of Sohag National Museum mark the key periods of Sohag history. Such focal objects draw links between past, present, and future; for example, the display of the statue of Thutmose III, the fifth pharaoh of the Eighteenth Dynasty and son or King Thutmose II is one of the major focal objects on the ground floor of the museum is reflecting the story of war, kingship and power where king Thutmose III, one of the greatest of Egypt's warrior pharaohs, which tells the story of the victory in ancient time.

The visitors of the ground floor can explore how stories add tangible value to the object. The Pilgrimage Barge Dated back to The Middle Kingdom of ancient Egypt and the statue of God "Osiris" highlight the story of the pilgrimage from the ancient time. The Osirid worship prevailed throughout the country during the 6 th dynasty (2323-2150 B.C.) and Abydos was its mai

Such focal objects utilize the importance of the city as a cult center. Coffins, Canopic jars, offering table, and ushapties are representing the ancient Egyptians beliefs in the resurrection the museum object carried out people tradition, thinking $\mathrm{New} \mathrm{K}$, a $\mathrm{Non}$. can undestand new viewpoints about ancient Foyptian social life.

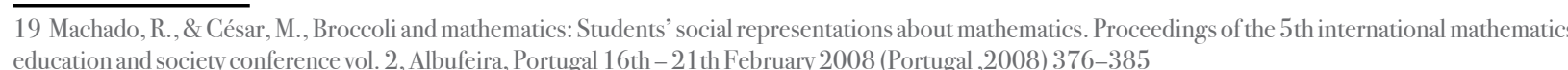
20 S. D. Schmidt and J. Schmidt, 'everyone has a story to tell: Examining digital storytelling in the classroom'. In C. Crawford et al. (eds.), Proceedings of
Society for Information Technology and Teacher Education. 2006. 


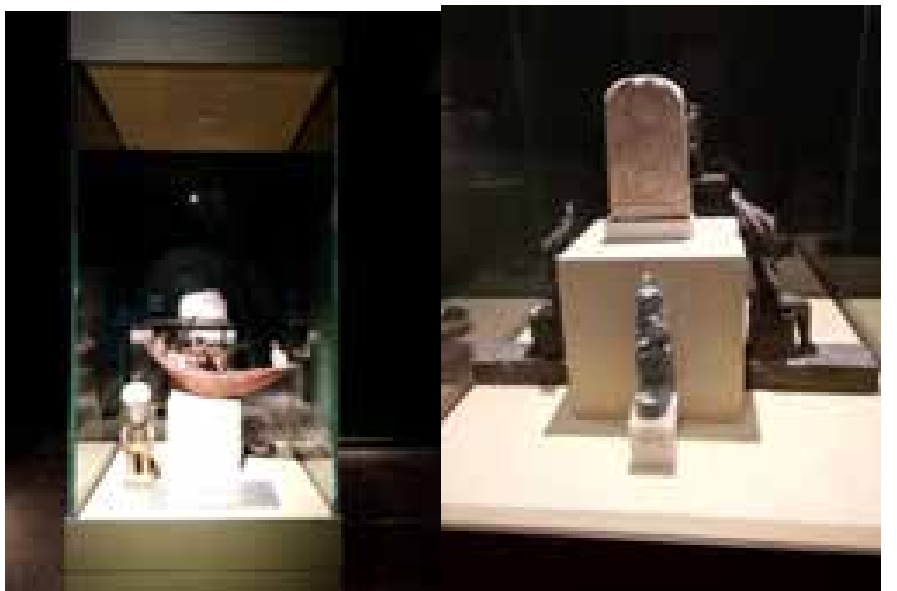

Fig.6. The photos show the ground floor gallery show collecions, the idea of Pilgrimage in

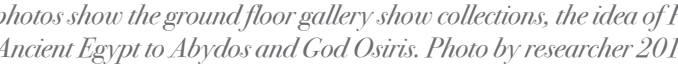

The museum has set a gallery with different textured textiles from different eras including ancient Egypt and the Ottoman Empire. Textile-making was a craft that was mastered by all society members. It was carried out in most houses or under the supervision of the goventin indicated the ilde of workshops being attached to temples. As linen textlle was essential and expensive, it was inherited within families. Families used to produce their needs and exchange surplus with other products for day-to-day needs. "Fig.7"

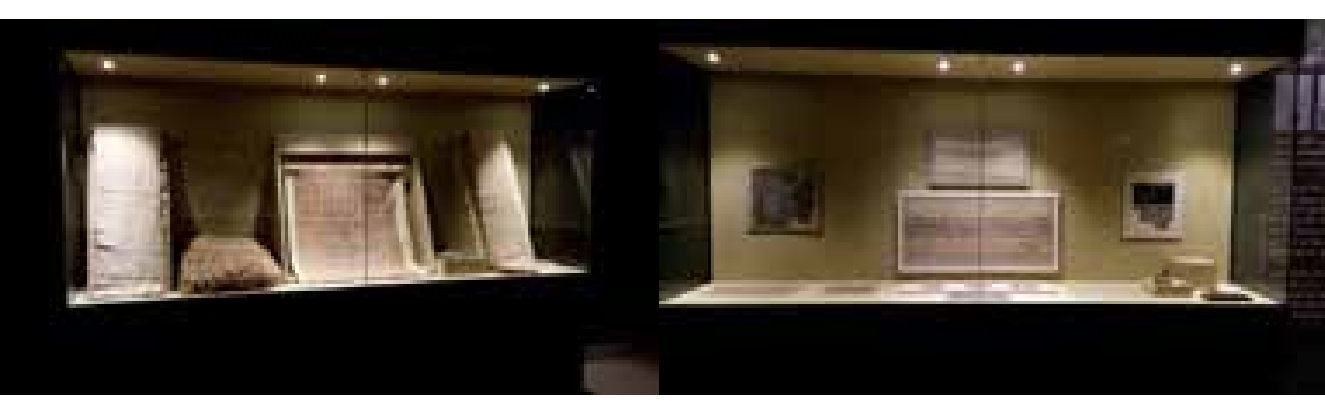

Fig.7. The photo shous she 5" gallery "Pharonic cextile and Islamic collections showcase" Photo by researcher 2018

Such collection tells the story of Sohag history in such an intangible aspect where Sohag, one of Egypt's oldest cities, is famous for its textile industry. The display of such focal objects in Sohag National Museum engages visitors; it acts as a medium demonstrating the history of Sohag and motivating visitors to create his or her own story after observing focal objects on display at the Museum. It is really important to supply the visitors with relevant and related information about the objects using int a collection and the related information about the objects, their documentation and interpretation into storics. The $2^{\text {nd }}$ element is the sensitive part which is the nirion

Using a theme this then they lived historiel tir lincs

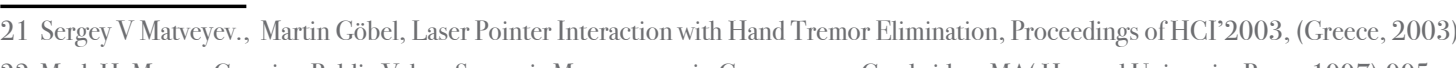
22 Mark H. Moore, Greating Public Value: Strategic Management in Government. Cambridge, MA( Harvard University Press, 1997),995. 23 Interpretation could be as complex process and a continuous interaction between the museum and the interpreter. Many museums do not pay attention (1) W 24 Swan D. W.. \& Manjarrez, C. A., Children's Visitation to Libraries and Museums. Research Brief series, no. 1 (IMLS-2013-RB-01). Washington, ID The reason why storytelling is really important for entertaining the museum's audience is because it gives credibility to the facts.
It increases the interest in knowledge and stimulates its thirst. Storytelling is the best way for communication. Not only kids It increases the intest in knowledge and stimwites its hirst. Storytelling is the best way for communication. Not only kid but also people or all is like storytelling; it is 25 . We 10 . ears. We interpret

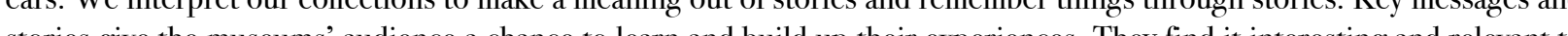
their lives Using storyelling is a fo

\section{Visitor Analysis}

The plan of the museums' Sector at the Egyptian Ministry of Antiquities focuses on setting an extensive, fully engaged, substantive dialogue and partnership with the people who hold the heritage. One of the major tasks of the museums' Sector at the Egyptian Ministry of Antiquities is to overcome prejudices of class difference and taste, recognizing a diversity of legitimate aesthetics and values.

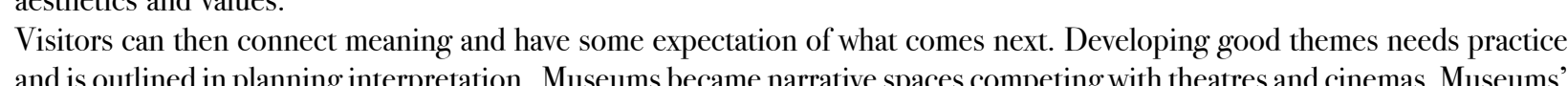
storytelling is a medium with scenography ${ }^{27}$ There are collections' interpretation, prined intepretation tools, and guided tours by curors and museums' educator ${ }^{23}$. Cultural history yields itself easily to storytelling but good stories ces be made from history events and tings. Creating or using chars. discover and reveal information through the telling of a story. "Fig.8" The way of collections displays, the visual and textual narratives produced and reproduced in museums have the power to produce meanings that work towards constructing septic social formations. ${ }^{29}$

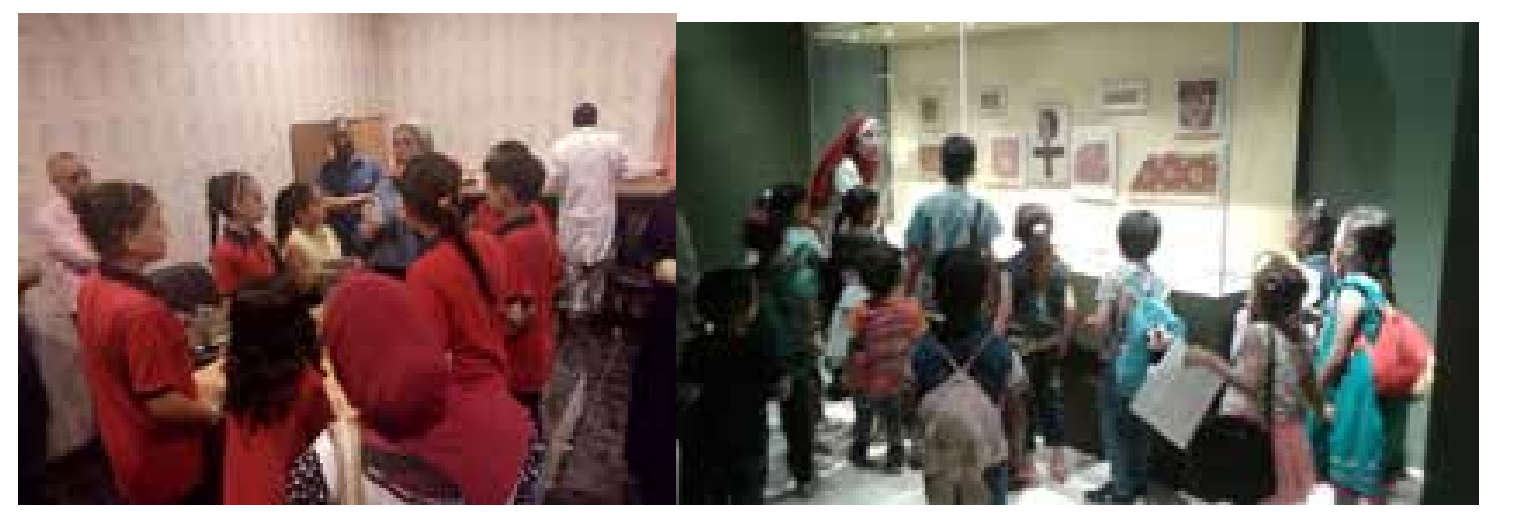

Fig.8. The photos show Primary Schoolsudents shrough their rourfor "hands on" workshhop, Photo by Sohag Musseum Curator 2018

The Egyptian Museums 'sector set a special marketing plan for Sohag National Museum by training the museum staff and developing a new type of educational programs. Sohag museum' volunteers offered the cost and to design the museum floor space in front of the library and the lecture room with different shapes of ancient Egyptian animals, plants, birds, flowers,

25 Suzan. Ghose, "Rethinking Museums: The Emerging Face of Story-telling Museums, (University of Victory Legacy Art Galleries (n.d.) 2014)

26 Elizabeth Grugeon, Paul Gardner, the art of storytelling for teachers for pupils, ( New York, 2000),20-40

27 Christer Gustafsson, Akram Ijla. "Museums: An incubator for sustainable social development and environmental protection", International Journal of

28 Lynda Kelly, the interrelationships between Adult museum visitors' Learning Identities and their museum experiences, University of Technology (Sydne,

9 Francessca Polleta. It was like a fever: Storvelling in protest and politics, (Chicago: The University of Chicago Press. 2006). 
vegetables, fruits, numbers and alphabet in Arabic and English Languages. Fig.9” The museum educators set up several interative preschool programs for children to have knowledge about ancient Egyptian animals, plants, birds, flowers,

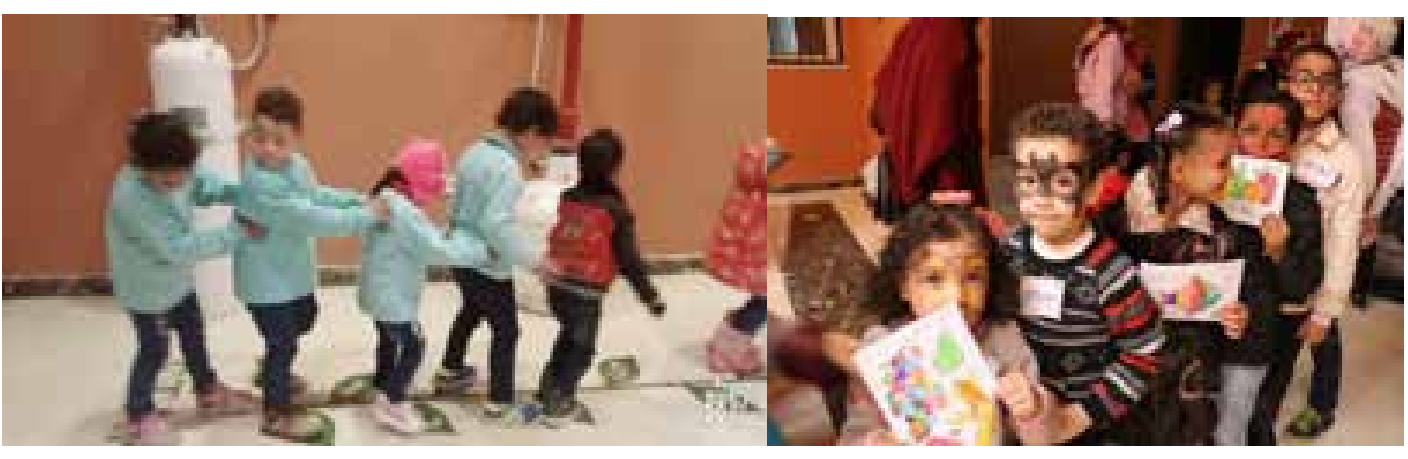

Fig.9. The photos show Lifelong learning for preschool kids "Numbers and leterers" in Sohag. Photo by Sohag Museum Curator 20 to

On the basis of the Information Unit of the Museums' Sector Analysis and the Marketing department of Sohag Museum situation analysis in the recent three months, most of the visitors of Sohag Museum know about the Museum from the official page of the Museun on Facebook; over 30\% of the visitors visit the Museum because their friends recommended the visit. Very few num . Most of the viston of So the vist (here where roviding the Musce of prove gallery: the visitors learn about the history of Sohag in different eras.
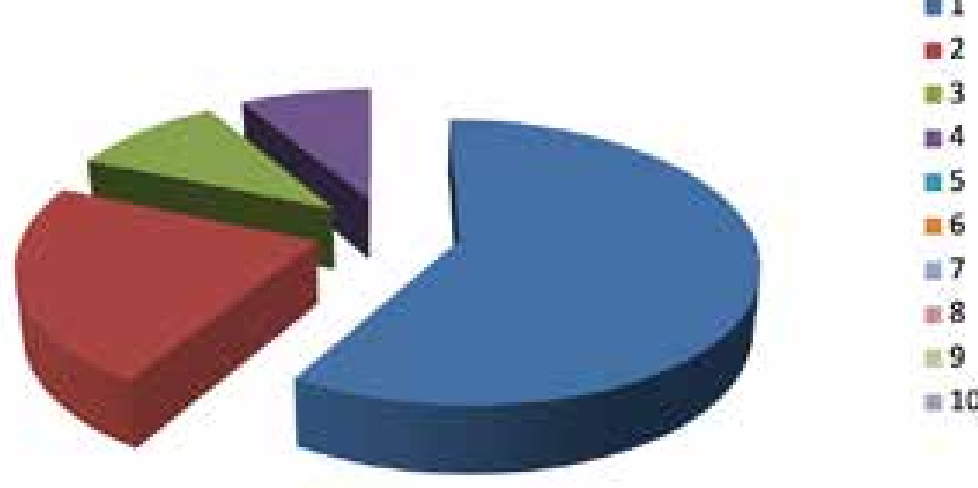

Fig. 10. Questionnaire, survey statsistis on museum duration visit and satisfaction

\section{Conclusion}

Sohag National Museum is a museum with a new approach of display that tells the story of one of the Upper Egypt governorates. Storytelling is the keyword in the display; it is a great medict focal object in every gallery. Such focal objects are telling the story of war, life, and joy from a different perspective. The visitor of Sohag National Museum understand the function and meaning of the object stating the clearness of the story in every gallery. The story of Sohag museum display sheds the light on the grassroots of Egyptian culture. Display through storytelling has become a powerful tool that has helped museums engage the audiences. Such an approach can build relationships within the 


\section{Bibliography:}

JOSEPH S. NYE JR., "Soft Power and American Foreign Policy", the journal of public and international affairs, Academy of political science Volume1 19, Issue2, (Summer 2004) 255-270

Behmer, Stacy, Schmidt-Crawford, Denise, Schmidt, Jane, Everyone Has a Story to Tell: Examining Digital Storytelling in the Classroom, In C. Crawford et al. (eds.), Proceedings of Society for Information Technology and Teacher Education International Conference, (VA: Association for the Advancement of Computing in Education ( 2006), 655-662

Gail Dexter Lord, Ngaire Blankenberg, Introduction: Why Cities, Museums and Soft Power, ( Washington, DC: The AAM Press American Alliance of Museums, 2015) ,.

Joseph Nye, Soft Power and American Foreign Policy, the journal of public and international affairs, Academy of political science Political Science Quarterly. 119,(June 2004) 255-270

Tony. Bennett, 1995, The Birth of the Museum: History, Theory, Politics (Culture: Policy and Politics) 1st Edition, (London: Routledge 1995) 92-102

Louise Ravelli., Making Language Accessible :Successful Text Writing for Museum Visitors, Linguistics and Education 8 (England The University of New South Wales , 1996, ) 367-387

Ted Ansbacher, making exhibits engaging and interesting. Curator Museum Journal, Volume45, Issue3 (July 2002, 167-173. Barbara J. Soren, Museum experiences that change visitors, Museum Management and Curatorship Volume 24, - Issue 3, 2009 ) 233-251

Peter Hasler, Visitors to Museums \& Galleries in the UK, the Council for Museums, Archives and Libraries Journal (London, 2001),50-53

Beverly Serrell, Paying Attention: Visitors and museum exhibitions, (Washington :American Association of Museums, 1998)100-150

Michael O. Martin, Ina V.S. Mullis, Albert E. Beaton, Eugenio J. Gonzalez, Teresa A. Smith, and Dana L. Kelly, Science achievement in the primary school years: IES's third international mathematics and sciences study (TIMSS), ( Center for the Study of Testing, Evaluation and Educational Policy, Boston College, 1997),

Ellien Hooper-Greenhill., Education, communication and interpretation.( Routledge, 2006) p76-103

Hannah Paddon, Redisplaying Museum Collections: Contemporary Display and Interpretation in British Museums 1st Edition, London, 2014), 100-184

Walter B Emery, A funerary repast in an Egyptian tomb of the archaic period, Leiden, Nederlands Instituut voor het Nabije Oosten, 1962),

Machado, R., \& César, M., Broccoli and mathematics: Students’ social representations about mathematics. Proceedings of he 5th international mathematics education and society conference vol. 2, Albufeira, Portugal 16th - 21th February 2008 (Portugal ,2008) 376-385

Sergey V Matveyev., Martin Göbel, Laser Pointer Interaction with Hand Tremor Elimination, Proceedings of HCI'2003, (Greece, 2003)
Mark H. Moore, Creating Public Value: Strategic Management in Government. Cambridge, MA( Harvard University Press, 1997),995

Suzan. Ghose, "Rethinking Museums: The Emerging Face of Story-telling Museums, (University of Victory Legacy Art Galleries (n.d.) 2014)

Elizabeth Grugeon, Paul Gardner, the art of storytelling for teachers for pupils, ( New York, 2000),20-40

Christer Gustafsson, Akram Ijla., "Museums: An incubator for sustainable social development and environmental protection”, International Journal of Development and Sustainability,.Vol. 5 No. 9, (2016) pp. 446-462.

Lynda Kelly, the interrelationships between Adult museum visitors' Learning Identities and their museum experiences, University of Technology ( Sydney, 2007).

Francessca Polleta, It was like a fever: Storytelling in protest and politics, (Chicago: The University of Chicago Press. 2006). 